\title{
Odds ratio analysis in women with endometrial cancer
}

\author{
Katarzyna Plagens-Rotman, Ewa Żak, Beata Pięta
}

Department of Mother's and Child's Health, Poznan University of Medical Sciences, Poznan, Poland

\begin{abstract}
Introduction: Despite the progress in diagnosis and treatment of malignant tumours, the effects of treatment are insufficient. Reduction of the risk of cervical, ovarian, and endometrial cancer is possible by introducing preventative actions.

Aim of the study: The aim of the thesis is the analysis of selected risk factors that may affect the increase or decrease in the odds ratio of developing endometrial cancer.

Material and methods: The study was conducted among patients of the Gynaecology and Obstetrics Hospital of Poznań University of Medical Sciences in the years 2011-2013.

The research included a total of 548 female respondents aged between 40 and 84 years. Women responded to questions assessing elements of lifestyle such as consumption of alcohol, smoking, and eating certain groups of foods.

Results: The respondents consuming fruits and vegetables several times a week have a reduced risk of odds ratio and the $\mathrm{OR}$ is $0.85 ; 95 \% \mathrm{Cl}: 0.18-4.09$, compared to the women who rarely consume vegetables and fruits. Consumption of whole-wheat bread several times a week reduces the risk of developing the cancer, OR $=0.59$; $95 \% \mathrm{Cl}$ : 0.14-2.47, compared to women not consuming wholegrain bread at all. Respondents who consumed red meat, such as veal, pork, and lamb in the amount of 101-200 g per day have an increased risk of developing the disease: $\mathrm{OR}=2.16 ; 95 \% \mathrm{Cl}: 1.09-4.28$, compared to women not consuming red meat at all.

Conclusions: A diet rich in fruit and vegetables, onions, garlic, whole grains, and beans should be introduced in order to reduce the risk of endometrial cancer. The consumption of red meat and white pasta should be reduced or even eliminated.
\end{abstract}

Key words: endometrial cancer, risk factors, the odds ratio of developing the disease.

\section{Introduction}

Endometrial cancer takes sixth place among women's cancers in the world, and second place among reproductive organ cancers, immediately after cervical cancer $[1,2]$.

The world records show approximately 189,000 new cases of endometrial cancer and 45,000 deaths a year [3]. The highest incidence rates occur in North American, European, and Australian countries, while the lowest are in countries in Asia and Africa [4].

According to data from GLOBOCAN, the incidence of endometrial cancer in Poland in 2008 amounted to 2176 cases, involving 3995 women under 65 years of age and 1819 cases of women aged 65 years and over [2].

In 2008, the estimated number of deaths due to endometrial cancer in Poland amounted 966,308 among women under 65 years of age and 658 among older women [2].

On the basis of histopathological classification, there are two types of endometrial cancer [4-7]. 70-80\% of cases are cancers of the first type (type I) - glandular en- dometrioidal cancers associated with unbalanced oestrogen stimulation, most often preceded by endometrial hyperplasia and expression of oestrogen and progesterone receptors [4, 8-10]. Increased incidences of obesity $[11,12]$, diabetes [13, 14], and high blood pressure [15] occur in type I. In contrast, type II, serous cancer is diagnosed more often among older women [4].

The development of the cancer process shows an association with genetic, reproductive, and hormonal factors. Numerous epidemiological research has also proven an association with lifestyle as well as with environmental and, endogenously, constitutional factors [16].

According to contemporary knowledge, a correctly balanced diet and physical activity are vital in the prevention of endometrial cancer. Vegetables and fruits are a rich source of numerous vitamins of antioxidant properties and macro- and trace elements that can act as inhibitors of tumour induction and development. The intake of food rich in vitamin $C$ decreases the risk of endometrial cancer as well as breast cancer. The mechanism of the protective effect of ascorbic acid is the 
result of $\mathrm{H}_{2} \mathrm{O}_{2}$ production in cancer cells, blocking the secretion of hyaluronidase, stimulating immunity, and inhibiting lysosomal glycosidases that increase the probability of developing cancer in the body [17].

Epidemiological research $[17,18]$ demonstrated the impact of phytoestrogens for inhibition of carcinogenesis by enhancing apoptosis in cancer cells, inhibiting intracellular signal transduction, blocking translocation of NF-KB nucleus, and inhibiting angiogenesis and antioxidants. They may affect the decrease in the risk of endometrial cancer and breast cancer. Moreover, the consumption of coffee and whole-grain foods may help protect against the development of endometrial cancer. The impact of vitamin D and calcium on the development of endometrial cancer is still ambiguous [19].

Epidemiological studies [20] indicate an increased risk of endometrial cancer in result of the consumption of red meat. This is probably caused by the formation of heterocyclic amines and polycyclic aromatic hydrocarbons during the processing of meat at high temperatures. Furthermore, nitrates or nitrites contribute to the formation of nitrosamines, damaging DNA.

Regular physical activity helps to maintain correct body weight by keeping balance between the intake of calories and energy expenditure. Furthermore, it affects the secretion of sex hormones, insulin, and prostaglandin [21]. Physical activity of 45 to 60 minutes a day, five days or more per week is recommended.

An appropriate preventive treatment involving the dietary recommendations and physical activity can play a significant role in prevention of many diseases, including endometrial cancer.

\section{Aim of the study}

The purpose of the research is to select chosen risk factors affecting the increase or decrease in the odds ratio of developing endometrial cancer.

\section{Material and methods}

The study involved healthy women without diagnosed malignant changes in reproductive organs, as well as women who, on the basis of histopathological examination of material obtained while scraping the walls of the uterus or during surgery, were diagnosed with endometrial cancer $(n=68)$.

In the group of healthy patients $(n=480)$ a correct result in the range of subjective and objective study carried out by the specialist and the lack of deviation in the vaginal ultrasound examination were taken into account.

The research was conducted among patients of the Gynaecology and Obstetrics Hospital of the University of Medical Sciences in the years 2011-2013. The study involved a total of 548 women aged 40 to 84 years.

A questionnaire survey consisting of 78 questions was used in the study. The survey questions contained elements of demographic characteristics (age, education, place of residence) and anthropometric data (weight, height). Moreover, women responded to questions assessing elements of lifestyle such as consumption of alcohol, smoking, and eating certain groups of food.

The questionnaire contained questions evaluating physical activity both in professional work and at leisure. The interviewed women chose from 14 different forms of activities (e.g. walking, cycling, sports, dance, gymnastics, passive resting with a newspaper), which they participated in before becoming diagnosed with cancer. Each type of physical activity was assigned appropriate intensity units of physical effort. In order to determine the intensity of the performed activity, each intensity unit was assigned to its metabolic equivalent specified in METs.

MET (metabolic equivalent): the ratio of the work metabolic rate to the resting metabolic rate. One MET is defined as $1 \mathrm{kcal} / \mathrm{kg} /$ hour and is roughly equivalent to the energy cost of sitting quietly. A MET also is defined as oxygen uptake in $\mathrm{ml} / \mathrm{kg} / \mathrm{min}$ with one MET equal to the oxygen cost of sitting quietly, equivalent to $3.5 \mathrm{ml}$ $\mathrm{kg} / \mathrm{min}[22]$.

The estimated physical activity has been expressed in MET units, as a product of the following parameters: the value of MET factor, the number of days of its performance per week and its duration in minutes per day. The respondents were divided into one of three categories of activity: low (less than 600 MET), moderate (600-1500 or 600-3000 MET), or high (higher than 1500 or $3000 \mathrm{MET}$ ) helped to determine the MET factor [22].

The odds ratios for particular risk factors were determined (Table I).

The chance of developing endometrial cancer, when the risk factor occurred, was calculated:

$$
\text { Chance/yes }=\frac{\frac{a}{a+c}}{1-\frac{b}{b+d}}
$$

and when it did not occur:

$$
\text { Chance/no }=\frac{\frac{b}{b+d}}{1-\frac{b}{b+d}}
$$

As a measure of the relative risk, the odds ratio (OR) and its 95\% confidence interval (CI) were calculated using logistic regression.

$$
\mathrm{OR}=\frac{\mathrm{a} \times \mathrm{d}}{\mathrm{c} \times \mathrm{c}}
$$




\section{Statistical analysis}

Estimations were made with the use of the statistical package StatSoft, Inc. (2011), STATISTICA (data analysis software system), version 10 .

Odds ratio with $95 \%$ confidence interval was determined with the use of a logistic regression model. The significance of the odds ratio was examined with a test with the following statistical hypothesis - HO: $\mathrm{ORi}=1, \mathrm{H} 1: \mathrm{ORi} \neq 1$. The Wald test statistic was used in the research. The statistics have asymptotic $\chi^{2}$ distribution with one degree of freedom, and based on $p$ value compared with a significance level $\alpha=0.05$ the decision was made: if $p \leq \alpha$ rejected $\mathrm{HO}$ accepted $\mathrm{H} 1$, if $p>\alpha$ there was no reason to reject $\mathrm{HO}$.

The research was approved by the Bioethics Committee of the University of Medical Sciences in Poznan, approval no. 574/11.

\section{Results}

Age was an analysed parameter. The odds ratio of developing endometrial cancer in women in different age groups: 40-49 years, 50-59 years, 60-69 years, 7079 years, and over 80 was calculated. The following results were obtained: OR for the group of respondents aged $50-59$ years 4.91 ; $95 \% \mathrm{Cl}: 1.79-13.49$, for women 60-69 years, OR $=25.17 ; 95 \% \mathrm{Cl}: 9.40-67.38$, and for respondents aged 70-79 years, OR $=37.12 ; 95 \%$ $\mathrm{Cl}: 11.56-119.20$. In the latter age group $O R=23.20$; 95\% Cl: 1.80-299.74.

The results are shown in Fig. 1.

The risk of developing endometrial cancer was reduced in women with higher and secondary-school education. Another parameter was the BMI value. Obese

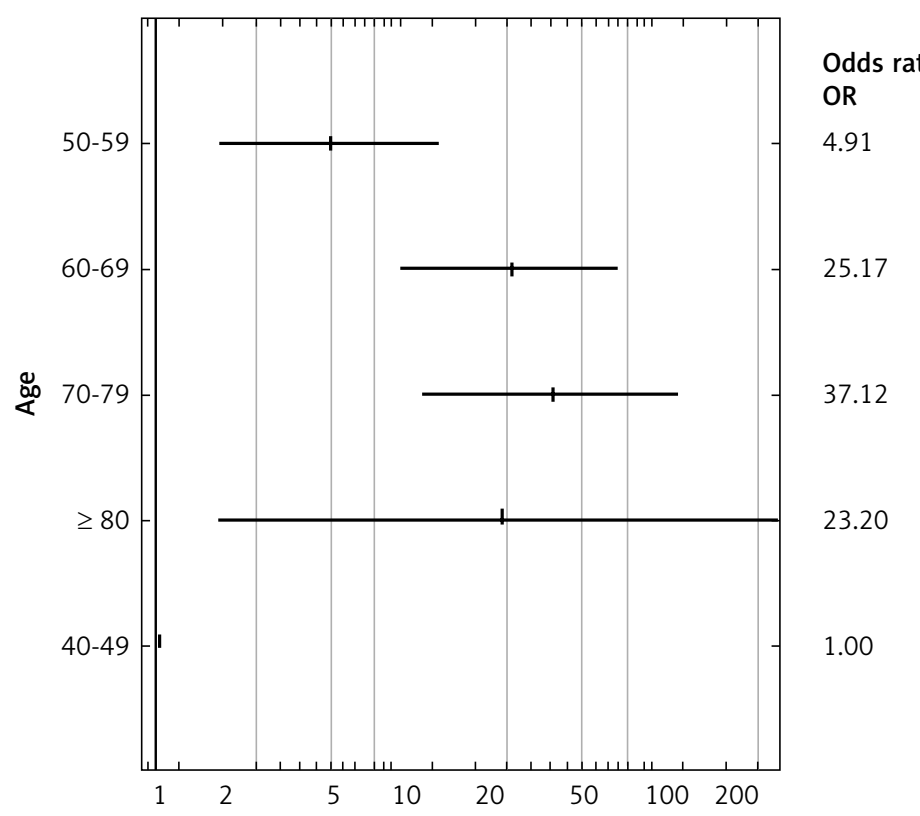

Fig. 1. OR of endometrial cancer according to age women with $\mathrm{BMI}$ of 30-34.9 have the risk increased five times, while for the respondents with BMI of 35-39.9 $\mathrm{OR}=9.74 ; 95 \% \mathrm{Cl}: 3.75-25.29$. Women with $\mathrm{BMI} \geq 40$ have almost 40 -times higher risk of developing endometrial cancer, $\mathrm{OR}=39.46 ; 95 \% \mathrm{Cl}: 10.71-145.33$. The results are shown in Fig. 2.

Respondents from large urban areas over 500,000 inhabitants, have a reduced risk of developing cancer $\mathrm{OR}=0.58 ; 95 \% \mathrm{Cl}: 0.28-1.21$, compared to women from villages with the number of inhabitants between 10,000 to 50,000 .

Women consuming wholemeal bread several times a week, have a reduced risk of developing the disease, with odds ratio standing at $\mathrm{OR}=0.59 ; 95 \% \mathrm{Cl}$ : 0.14 2.47, compared to women not consuming wholemeal bread at all.

The impact of red meat consumption such as veal, pork, and lamb on the decrease or increase in the risk of developing endometrial cancer was analysed. For the respondents consuming 101-200 g of red meat per day, the risk is raised and the odds ratio is at $O R=2.16 ; 95 \%$ $\mathrm{Cl}$ : 1.09-4.28, compared to women not consuming red meat at all.

The consumption of dairy products such as yogurt and kefir enriched with live bacteria in the amount of one piece (125 g) per day reduces the risk of illness, $\mathrm{OR}=0.87 ; 95 \% \mathrm{Cl}: 0.42-1.80$. Women who consume two pieces $(250 \mathrm{~g}$ ) of dairy a day, have the odds ratio of developing cancer equal $\mathrm{OR}=0.25 ; 95 \% \mathrm{Cl}$ : 0.07-0.97, compared to women not consuming dairy products at all. The results are presented in Table I.

Women who eat one bulb of onion and one clove of garlic a day have a reduced risk, with odds ratio $\mathrm{OR}=$ 0.73; 95\% Cl: 0.36-1.48, compared to women not consuming onion and garlic at all.

$\begin{array}{lcc}\begin{array}{l}\text { Odds ratio } \\ \text { OR }\end{array} & \text { Interval of confidence } & p>0.05 \\ 4.91 & (1.79-13.49) & 0.0020 \\ 25.17 & (9.40-67.38) & 0.0000 \\ 37.12 & (11.56-119.20) & 0.0000 \\ 23.20 & (1.80-299.74) & \\ & & 0.0160\end{array}$




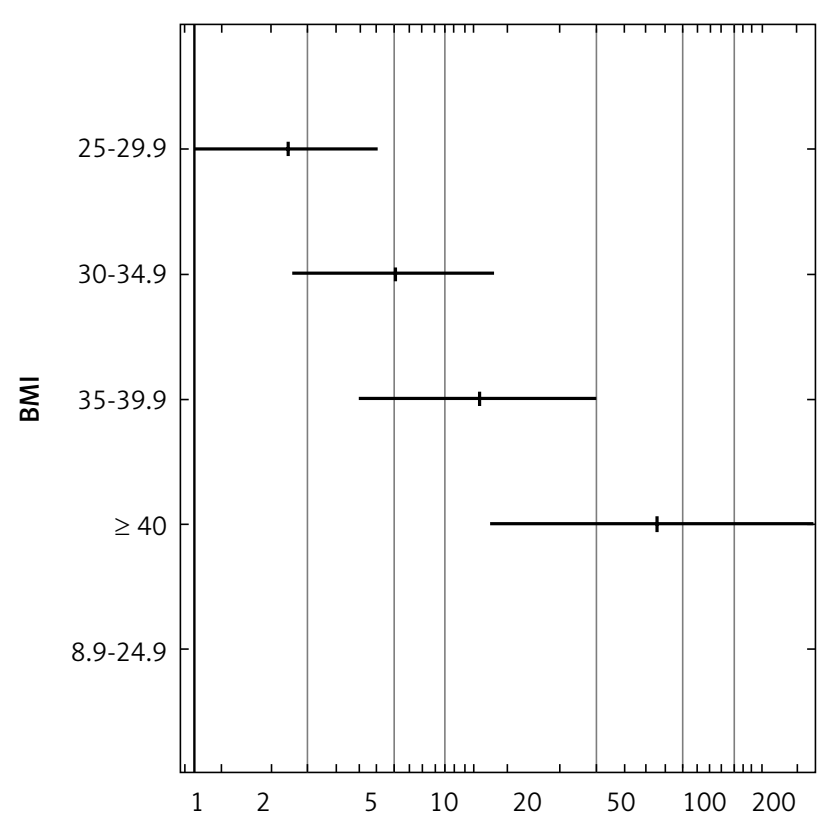

Fig. 2. OR of developing endometrial cancer depending on BMI

Women consuming up to $100 \mathrm{~g}$ of Basmati rice a day have a decreased risk of developing endometrial cancer. OR for this group of women reached the level of $0.57 ; 95 \% \mathrm{Cl}: 0.20-1.64$, and for women consuming wild rice OR equals 0.79; $95 \% \mathrm{Cl}$ : 0.27-2.30.

Women consuming $100 \mathrm{~g}$ of white pasta per day, have the risk of developing cancer increased twice.

OR for this group of women is at level: 2.14; $95 \%$ $\mathrm{Cl}$ : 0.99-4.61, while for women consuming up to $100 \mathrm{~g}$ wholemeal pasta, soy, and wheat per day, OR was as follows OR: $0.41 ; 95 \% \mathrm{Cl}$ : 0.18-0.93, OR $=0.32 ; 95 \% \mathrm{Cl}$ : $0.04-2.45, \mathrm{OR}=0.74 ; 95 \% \mathrm{Cl}: 0.37-1.46$. The results are presented in Table II.

In the respondents consuming $100 \mathrm{~g}$ of pearl barley a day, the risk of developing endometrial cancer is reduced. The level of OR in this group of respondents amounts to $0.52 ; 95 \% \mathrm{Cl}: 0.16-1.73$.

Women consuming 10 tablespoons of olive oil a day, the odds ratio of developing the disease is as follows: $\mathrm{OR}=0.70 ; 95 \% \mathrm{Cl}: 0.40-1.21$, compared to women not consuming olive oil at all.

The next parameter for which the odds ratio of developing cancer was calculated is the number of cigarettes smoked and consumption of alcohol and coffee.

Tab. I. OR of endometrial cancer development in relation to the amount of dairy products consumed per day

\begin{tabular}{lcc}
\hline $\begin{array}{l}\text { Dairy products } \\
\text { (in pieces) }\end{array}$ & Odds ratio (OR) & $\begin{array}{c}\text { The confidence } \\
\text { interval 95\% }\end{array}$ \\
\hline 1 & 0.87 & $0.42-1.80$ \\
\hline 2 & 0.25 & $0.07-0.97$ \\
\hline
\end{tabular}

$\begin{array}{lcc}\begin{array}{l}\text { Odds ratio } \\ \text { OR }\end{array} & \text { Interval of confidence } & p>0.05 \\ 2.10 & (1.03-4.32) & 0.0426 \\ 4.96 & (2.23-11.05) & 0.0001 \\ 9.74 & (3.75-25.29) & 0.0000 \\ & & \\ 39.46 & (10.71-145.33) & 0.0000\end{array}$

1.00

The odds ratio (OR) of developing the disease amounts to $\mathrm{OR}=0.35 ; 95 \% \mathrm{Cl}: 0.12-0.99$ for the respondents who smoke up to 10 cigarettes a day, compared to the women who never smoked.

Women consuming up to $100 \mathrm{ml}$ of alcohol a day have odds ratio of developing the disease equal to $\mathrm{OR}=0.08$; $95 \% \mathrm{Cl}: 0.03-0.22$, in comparison with women not consuming alcohol.

Respondents consuming one cup of coffee a day have a decreased risk of developing endometrial cancer. OR reached the level of $0.66 ; 95 \% \mathrm{Cl}$ : 0.44-0.77, when compared to the respondents who did not consume coffee at all. Not without significance for the increase or decrease of the odds ratio of developing endometrial cancer is also consumption of cruciferous vegetables (cauliflower, broccoli, cabbage, radish, lettuce), red vegetables (carrots, tomatoes, peppers, beets), and citrus fruits (oranges, tangerines, grapefruits, lemons, apples, bananas, kiwi). For women consuming fruits and vegetables several times a week, the odds ratio amounts $\mathrm{OR}=0.85 ; 95 \% \mathrm{Cl}: 0.18-4.09$, compared to respondents who rarely consume vegetables and fruits.

The attempt to estimate the odds ratio of developing endometrial cancer was based on the following parameters: physical activity during housework, sports activi-

Tab. II. OR of endometrial cancer in relation to daily intake of pasta

\begin{tabular}{lcc}
\hline $\begin{array}{l}\text { A type of pasta } \\
\text { (100 g a day) }\end{array}$ & Odds ratio (OR) & $\begin{array}{c}\text { The confidence } \\
\text { interval 95\% }\end{array}$ \\
\hline White pasta & 2.14 & $0.99-4.61$ \\
\hline Wholemeal pasta & 0.41 & $0.18-0.93$ \\
\hline Soy pasta & 0.32 & $0.04-2.45$ \\
\hline Wheat pasta & 0.74 & $0.37-1.46$ \\
\hline
\end{tabular}


ties, passive resting, and effort. The following types of activity were adopted: low (less than $600 \mathrm{MET}$ ), moderate (600-1500 MET), and high (above $1500 \mathrm{MET}$ ). The risk of developing the endometrial cancer increased in the respondents declaring undertaking sports activities between 600 and $1500 \mathrm{MET}, \mathrm{OR}=1.16$; 95\% Cl: 0.58-2.33, and the risk increases 1.73 -fold, $\mathrm{OR}=1.73 ; 95 \% \mathrm{Cl}$ : $0.95-$ 3.15 in the women with activity over $1500 \mathrm{MET}$, compared to women taking physical activity below 600 MET.

Moderate and high physical activity undertaken during domestic work reduces the risk of endometrial cancer, and the odds ratio is as follows: $O R=0.25$; $95 \% \mathrm{Cl}: 0.04-1.65$ - for the group with moderate physical activity and $\mathrm{OR}=0.28 ; 95 \% \mathrm{Cl}: 0.05-1.57$ - for the group with high activity, compared to the ratio of low intensive activity. The respondents undertaking passive relaxation in the range of 600-1500 MET a day are at increased risk, and odds ratio $\mathrm{OR}=1.62 ; 95 \% \mathrm{Cl}$ : 0.78 3.38 , compared to the respondents with low physical activity (less than $600 \mathrm{MET}$ ).

\section{Discussion}

Endometrial cancer is a common female genital cancer of industrialised countries [23-25]. This phenomenon is related to the occurrence of obesity, diabetes, inadequate physical activity, high number of offspring conceived, or infertility [26]. Other factors are advanced age of women, early first and last menstruation, menstrual disorders, and receiving oestrogen hormone replacement therapy or tamoxifen [3, 27].

Symptoms of $90 \%$ of diagnosed endometrial cancers are abnormally prolonged bleeding, heavy menstrual bleeding, and irregular intermenstrual bleeding. The remaining $10 \%$ are vaginal discharge. Abdominal and sacral pain occur in the third and fourth clinical stage of cancer and are caused by compression and infiltration on the plexus. Enlargement of the uterus caused by haematoma or abscess of the uterine cavity, which causes swelling of the lower extremities, is also observed [27].

The incidence of endometrial cancer increases with age. It is a rare disease in women under 45 years old and its occurrence in general incidence is estimated at $10 \%$. The highest incidence rate in Poland occurs between 60 and 69 years of age. This relation can be observed in our study, the average age of patients with endometrial cancer was 62.5 years. The odds ratio calculated in our work increases with age. Women aged between 70-79 are at highest risk with $\mathrm{OR}=37.12$; 95\% Cl: 11.56-119.20.

A total of 5125 new cases of endometrial cancer were diagnosed in Poland in 2010, a total of $7.3 \%$ of all cancer cases in women. Raw and standardised incidence rates for this type of cancer in Poland in 2010 amounted respectively 25.8 and 14.8 per 100,000 wom- en, respectively [28]. Based on epidemiological studies, one can conclude that the incidence of endometrial cancer is associated with good social and economic conditions. Upper-class women, who had menopause, are more likely to apply hormone replacement therapy preventing the deficiency of oestrogen. This results in an increased risk of endometrial cancer [27].

The risk of developing endometrial cancer in Caucasian women, with higher education, is four times higher than in case of coloured and uneducated women [27].

Our research showed that educated women have a lower odds ratio of developing the disease: $O R=0.43$; 95\% Cl: 0.25-0.76, compared to women who completed vocational education. This is probably due to increased awareness, regular testing, and early diagnosis of malignancy.

The correlation between obesity and increased risk of developing endometrial cancer has been the subject of many studies [29-32]. In European countries, 5\% of newly diagnosed malignancy cases indicate a relation with overweight. The largest number of endometrial cancer (39\%) and breast cancer cases are observed in postmenopausal women. The following places in the above ranking are renal cancer, colorectal cancer, and gallbladder disease [33, 34].

The adverse effect of obesity on endometrium is related to the increased level of oestrogens by aromatisation of androgens in the adipose tissue. These disorders are additionally intensified by type 2 diabetes and increased levels of hyperinsulinaemia as well as insulinlike growth factor (IGF-1). A high level of insulin leads to an increase in pot unbound active sex hormones in blood, stimulation of androgen production growth in adrenal glands and ovaries, and reduction of concentration of progesterone due to ovulation disorders. Insulin is assumed to act as a promoter of angiogenesis by increasing the expression of endothelial growth factor (VEGF) in tumour tissue [35-38].

It is estimated that approximately $70-90 \%$ of patients diagnosed with type I endometrial cancer are obese, and the degree of risk of cancer development is directly proportional to BMI. In the research of Weiderpass et al. [29] in women with BMI between 28 and $29 \mathrm{~kg} / \mathrm{m}^{2}$ the risk of endometrial cancer was increased by $50 \%$, and between 30 and $33 \mathrm{~kg} / \mathrm{m}^{2}$ the risk was three times higher when compared to the control group. In women with $\mathrm{BMI}>34$ the risk was more than six times higher.

Average BMI value in our research was $31 \mathrm{~kg} / \mathrm{m}^{2}$, and it was higher than the average BMI in the group of women without malignant changes of genital organs and breasts. Furthermore, the analysis of the odds ratio of developing the disease allowed us to observe an increasing trend along with BMI values. The risk of developing endometrial cancer was almost 40-times higher in women with $\mathrm{BMI}$ over $40 \mathrm{~kg} / \mathrm{m}^{2}, \mathrm{OR}=39.46 ; 95 \% \mathrm{Cl}$ : 10.71-145.33. 
In the group of women with BMI $25-29 \mathrm{~kg} / \mathrm{m}^{2}$ the relative risk of death from endometrial cancer is at the level $O R=1.50$, and for a BMI of $30-34 \mathrm{~kg} / \mathrm{m}^{2}$ the $\mathrm{OR}=$ 2.53. $\mathrm{BMI}>40$ and the risk is above 6.25 [30].

In the studies conducted by Schouten et al. [31] in a group of 62,573 women, 226 cases of endometrial cancer were diagnosed. The authors also pointed out the correlation between patient height in and the risk of endometrial cancer development. The risk is more than 2.5-times higher in women with height above 175 $\mathrm{cm}$, compared to women with a height below $160 \mathrm{~cm}$.

In economically developed countries, $25-30 \%$ of deaths are caused by cancer, and the association with smoking is obvious. Epidemiological studies indicate that smoking is the cause of lung cancer in $87-91 \%$ of male cases and $57-86 \%$ of female. The percentage of oesophagus, throat, and mouth cancers associated with direct exposure to tobacco smoke or alcohol is 43$60 \%[33,39]$.

A report published by the World Health Organisation (WHO) [40] shows that passive smoking causes about 600,000 premature deaths each year, of which $31 \%$ are children and as many as $64 \%$ concern women. The research indicates the negative impact of passive smoking mainly on children of parents who smoke cigarettes at home, as well as on those who work in workplaces where smoking is allowed [41].

In a study by Parazzini et al. [42] on 1726 women with endometrial cancer and 1452 women in the control group, the risk of developing the disease was at OR $=0.8$ and 0.6, respectively, for women who stopped smoking. The risk of endometrial cancer was reduced, but it depended on the number of cigarettes smoked per day and the duration of the habit. Similar results were obtained in a study by Zhou et al. [43], in which the risk of developing endometrial cancer was at OR $=0.81 ; 95 \% \mathrm{Cl}: 0.74-0.88$. Moreover, the authors observed a protective result of smoking in women who ended menstruation, $\mathrm{OR}=0.71 ; 95 \% \mathrm{Cl}: 0.65-0.78$. It is believed that the protective influence of tobacco on endometrial mucosa is associated with a reduction of the set of circulating oestrogen, promotion of 2-hydroxylation of estradiol, and a change of androgen metabolism. Furthermore, the effects of polycyclic aromatic bicarbonate on ovaries contributes to the loss of oocytes, and as a result, to early menopause [4].

In our analysis, the average amount of cigarettes smoked a day in women with endometrial cancer of the uterus amounted to 1.7 units, with a maximum of 20 units of cigarettes smoked.

Women smoking up to 10 cigarettes a day have an odds ratio $\mathrm{OR}=0.35,95 \% \mathrm{Cl}: 0.12-0.99$, compared to non-smoking women.

Tzonou et al. [44] in comparative studies analysed the nutrition of 145 women with endometrial cancer and 298 women with orthopaedic disorders represent- ing the control group. An increase in consumption of monounsaturated fats, particularly of olive oil, resulted in $26 \%$ reduction in the risk of developing endometrial cancer. The quoted authors found a weak relationship between the consumption of vegetables that play protective roles and legumes showing positive correlation with the risk of developing cancer of the lining of the uterus. This relationship may be due to an excessive supply of energy in pulses and insufficient exercise.

A protective effect of olive oil consumption was also shown in our study. The odds ratio of developing cancer for women consuming up to 10 tablespoons of olive oil a day was $\mathrm{OR}=0.70 ; 95 \% \mathrm{Cl}$ : 0.40-1.21, compared to women not consuming olive oil. This relationship results from the presence of a large amount of antiinflammatory antioxidants in olive oil.

Many authors $[45,46]$ emphasise the role of proper diet and physical activity in weight reduction. Epidemiological studies indicate a positive correlation between the consumption of high-calorie foods, fat, dairy products, and meat and the incidence of endometrial cancer.

Research by Pan et al. [47] show that the risk of developing endometrial cancer from eating fats and oil is on the level: $O R=5.0$, and in the case of increased supply of vegetables, green in particular, it is $O R=2.2$. A diet consisting of fresh fruit causes a reduction in risk of developing the disease to $\mathrm{OR}=0.6$.

In our analysis the consumption of fruit and vegetable by the respondents showed a decrease in the risk of developing endometrial cancer. The odds ratio of developing cancer in women eating fruits and vegetables several times a week was OR $=0.85 ; 95 \% \mathrm{Cl}$ : 0.18-4.09, compared to the women who often consume vegetables and fruits. The decrease in the risk of developing endometrial cancer is associated with the presence of many vitamins and macro- and micronutrients inhibiting angiogenesis and exhibiting antioxidant activity, in vegetables and fruits.

Bandera et al. [48] demonstrated in their metaanalysis that consumption of $100 \mathrm{~g}$ of products of animal origin per day increases the risk of developing endometrial cancer by $26 \%$. Consumption of red meat exclusively, increases the risk by $50 \%$. This relationship was also observed in our research. The odds ratio of developing a disease in the respondents eating 101-200 g red meat per day was $\mathrm{OR}=2.16 ; 95 \% \mathrm{Cl}: 1.09-4.28$, compared to women not consuming red meat at all.

According to the American Cancer Society guidelines [49], physical activity should be undertaken in order to prevent cancerous diseases, although the optimal intensity, duration, and frequency of exercise have not been established so far. The available research suggests that the risk may be reduced by moderate or intense physical exercise lasting over 30 minutes, not including the activities performed throughout the day. Physical activity lasting 45-60 minutes and performed 
at least five days a week is optimal to reduce the risk of breast cancer and colon cancer.

The study by Friedenreich et al. [50] demonstrated a relative risk of endometrium cancer for recreational activities undertaken at $\mathrm{OR}=0.68$ in women having intensive exercise, compared to women with low physical activity. Moreover, the risk stood at 1.28 in women with a sedentary lifestyle. A total of 777 cases of endometrial cancer were detected among nearly 72,000 women participating in the Nurses' Health Study conducted by Du et al. [51]. Additionally, the analysis indicated that undertaking moderate or high recreational activity gave the odds ratio of developing cancer 0.61 and 0.73 , respectively.

According to our research, moderate and high physical activity undertaken during the housework decreases the risk of endometrial cancer, and the odds ratio is as follows: for the group of moderate physical activity $\mathrm{OR}=$ $0.25 ; 95 \% \mathrm{Cl}: 0.04-1.65$, and for the highly active group $\mathrm{OR}=0.28 ; 95 \% \mathrm{Cl}: 0.05-1.57$, compared to physical activity of low intensity. The risk of developing cancer increases in respondents undertaking passive relaxation in the range of 600-1500 MET per day, and odds ratio OR = 1.62 is; $95 \% \mathrm{Cl}: 0.78-3.38$, compared to the respondents with low physical activity (less than $600 \mathrm{MET}$ ).

Further studies on commonly known lifestyle factors and their possible modifications may be the key in preventing the occurrence of new cases of endometrial cancers. Moreover, knowledge of the intensity of risk factors effectively contributes to the development of prevention programs and the rational use of funds designed for preventive measures.

\section{Conclusions}

The conducted study and analysis of the collected data allow the following conclusions to be drawn:

1. It is advisable to introduce a diet rich in fruits and vegetables, including bulb vegetables, and grain products that contain whole grains in order to reduce the risk of endometrial cancer.

2. Consumption of $100 \mathrm{~g}$ of wholemeal pasta, soya, and wheat a day is recommended.

3. Consumption of red meat and white pasta should be reduced or even eliminated.

4. Consumption of $250 \mathrm{ml}$ of dairy products such as yoghurt and kefir enriched with live bacteria a day is recommended.

5. There is a need to educate women, who have completed their education at vocational level and living in small urban areas, about risk factors of endometrial cancer.

\section{Disclosure}

Authors report no conflict of interest.

\section{References}

1. Grosman-Dziewiszek P, Dziegiel P, Zabel M. Disturbance of gene expression in endometrial cancer as therapy aim. Ginekol Pol 2011; 82: 276-280.

2. Ferlay J, Shin HR, Bray F, et al. GLOBOCAN 2008, Cancer Incidence and Mortality Worldwide: IARC CancerBase No. 10 [Internet]. International Agency for Research on Cancer; Lyon 2010.

3. Żyła MM, Kostrzewa M, Litwińska E, et al. The role of angiogenic factors in endometrial cancer. Prz Menopauzalny 2014; 13: 122-126.

4. Markowska J, Mądry R. Zarys ginekologii onkologicznej. [Outline of gynecological oncology]. Termedia, Poznań 2012.

5. Doll A, Abal M, Rigau M, et al. Novel molecular profiles of endometrial cancer - new light through old windows. J Steroid Biochem Mol Biol 2008; 108: 221-229.

6. Pawłowicz PS, Ajdacka U. The role of laparoscopy in the surgical treatment of endometrial cancer. Videosurgery Miniinv 2015; 10: 44-48.

7. Zając A, Stachowiak G, Stetkiewicz T, Wilczyński JR. TP53 gene and p53 protein vs. endometrial carcinoma. Prz Menopauzalny 2013; 3: 228-230.

8. Amant F, Moerman P, Neven P, et al. Endometrial cancer. Lancet 2005; 366: 491-505.

9. Baltaziak M, Kańczuga-Koda L, Rutkowski R, et al. Komunikacja międzykomórkowa z udziałem połączeń typu gap w karcinogenezie błony śluzowej trzonu macicy. [Gap junction intercellular communication in carcinogenesis of endometrial cancer]. Ginekol Pol 2011; 82: 520-524.

10. Gottwald L, Kubiak R, Pasz-Walczak G, et al. Znaczenie ekspresji receptorów progesteronowych i estrogenowych ocenianej metodą mikromacierzy tkankowych dla rokowania u chorych z gruczolakorakiem endometrioidalnym endometrium. [The value of progesterone and estrogen receptors expression in tissue microarray method in prognosis of patients with endometrioid endometrial Cancer]. Ginekol Pol 2013; 84: 95-101

11. Friedenreich C, Cust A, Lahmann PH, et al. Anthropometric factors and risk of endometrial cancer: the European prospective investigation into cancer and nutrition. Cancer Causes Control 2007; 18: 399-413.

12. Schouten L, Goldbohm R, van den Brandt P. Anthropometry, physical activity, and endometrial cancer risk: results from the Netherlands cohort study. Int J Gynecol Cancer 2006; 16 Suppl 2: 492.

13. Zendehdel K, Nyren O, Adami $\mathrm{H}$, et al. Cancer incidence in patients with type 1 diabetes mellitus: a population - based cohort study in Sweden. J Natl Cancer Inst 2003; 95: 1797-1800.

14. Friberg E, Mantzoros CS, Wolk A. Diabetes and risk of endometrial cancer: a population - based prospective cohort study. Cancer Epidemiol Biomarkers Prev 2007; 16: 276-280

15. Bratos K, Roszak A, Cikowska-Woźniak E, et al. Analiza czynników epidemiologicznych u chorych z rakiem błony śluzowej trzonu macicy leczonych w Wielkopolskim Centrum Onkologii. [Analysis of risk factors for endometrial neoplasia as a method for supplementation of indications for D\&C in postmenopausal women with uterine bleeding]. Ginekol Pol 2002; 76: 945-950.

16. Dębska-Szmich S, Czernek U, Krakowska M, et al. Synchronous primary ovarian and endometrial cancers: a series of cases and a review of literature. Prz Menopauzalny 2014; 1: 64-69.

17. Rotsztejn $\mathrm{H}$. The significance of fitoestrogens in the light of currant knowledge. Prz Menopauzalny 2005; 4: 47-50

18. Shannon JJ, Thomas D, Ray R, et al. Dietary risk factors for invasive and in situ cervical carcinomas in Bangkok, Thailand. Cancer Causes Control 2002; 13: 691-699.

19. McCullough ML, Bandera EV, Moore DF, Kushi LH. Vitamin D and calcium intake in relation to risk of endometrial cancer: a systematic review of the literature. Prev Med 2008; 46: 298-302.

20. Bravi F, Scotti L, Bosetti C, et al. Food groups and endometrial cancer risk: a case-control study from Italy. Am J Obstet Gynecol 2009; 200 293.e1- 293e7.

21. McTiernan A, Tworoger SS, Ulrich CM, et al. Effect of exercise on serum estrogens in postmenopausal women: a 12-month randomized clinical trial. Cancer Res 2004; 64: 2923-2928.

22. Ainsworth BE, Haskell WL, Whitt MC, et al. Compedium of physical activities: an update of activity codes and MET intensities. Med Sci Sports Exerc 2000; 32: S498-S504. 
23. Huddleston A, Zhen S, Qi L, et al. The impact of a vaginal brachytherapy boost to pelvic radiation in stage III endometrial cancer. J Contemp Brachytherapy 2015; 7: 122-127.

24. Stucan M, Zalewski K, Brabowski JP, et al. Creation of the Polish version and adaptation of the European Organisation for Research and Treatment of Cancer Quality of Life Questionnaire-Endometrial Cancer Module (QLQ-EN24). Contemp Oncol (Pozn) 2014; 2: 134-139.

25. Damast S, Higgins SA, Ratner E, et al. High-dose-rate vaginal brachytherapy with chemotherapy for surgically staged localized uterine serous carcinoma. J Contemp Brachytherapy 2015; 1: 35-40.

26. van der Steen-Banasik E. Primary brachytherapy as a radical treatment for endometrial carcinoma. J Contemp Brachytherapy 2014; 6: 106-112.

27. Markowska J, Markowska A. Onkologia ginekologiczna. [Gynaecological Oncology]. Urban \& Partner, Wrocław 2002.

28. Wojciechowska U, Didkowska J, Zatoński W. Nowotwory złośliwe w Polsce w 2010 roku. [Cancer in Poland in 2010]. Centrum Onkologii Instytut im. M. Skłodowskiej-Curie, Warszawa 2012.

29. Weiderpass E, Persson I, Adami HO, et al. Body size in different periods of life, diabetes mellitus, hypertension, and risk of postmenopausal endometrial cancer (Sweden). Cancer Causes Control 2000; 11: 185-192.

30. Calle EE, Rodriguez C, Walker-Thurmond K. Overweight, obesity, and mortality from cancer in a prospectively studied cohort of U.S. adults. N Engl J Med 2003; 348: 1625-1638.

31. Schouten L, Goldbohm R, van den Brandt P. Anthropometry, physical activity, and endometrial cancer risk: results from the Netherlands cohort study. Int J Gynecol Cancer 2006; 16 Suppl 2: 492

32. Moszyńska-Zielińska M, Chałubińska-Fendler J, Gottwald L, et al. Does obesity hinder radiotherapy in endometrial cancer patients? The implementation of new techniques in adjuvant radiotherapy - focus on obese patients. Prz Menopauzalny 2014; 13: 96-100.

33. Zatoński W. Europejski kodeks walki z rakiem. [European Code Against Cancer]. Centrum Onkologii - Instytut im. Marii Skłodowskiej-Curie, Warszawa 2011.

34. Wojtyła-Buciora P, Stawińska-Witoszyńska B, Klimberg A, et al. Nutrition-related health behaviours and prevalence of overweight and obesity among Polish children and adolescents. Ann Agric Environ Med 2013; 20: 332-340.

35. Tian YF, Chu CH, Wu MH, et al. Anthropometric measures, plasma adiponectin, and breast cancer risk. Endocr Relat Cancer 2007; 14: 669-677.

36. Baloglu A, Bezircioglu I, Cetinkaya B, Hicyılmaz L. Prospective clinical study of the association between plasma level of free IGF-1 and myometrial invasion in patients with endometrial adenocarcinoma. Ginekol Pol 2010; 81: 501-505.

37. Kancalska-Janssen O, Rajtar-Ciosek, Zmaczyński A, et al. Markers of insulin resistance in perimenopausal women with endometrial pathology. Ginekol Pol 2013; 84: 922-929.

38. Markowska A, Pawałowska M, Lubin J, Markowska J. Signalling pathways in endometrial cancer. Contemp Oncol (Pozn) 2014; 18: 143-148.

39. Panasiuk L, Mierzecki A, Wdowiak L, et al. Prevalence of cigarette smok ing among adult population in Eastern Poland. Ann Agric Environ Med 2010; 17: 133-138.

40. World Health Organisation Framework Convention on Tobacco Control 2003.

41. Fronczak A, Polańska K, Dziankowska-Zaborszczyk E, et al. Changes in smoking prevalence and exposure to environmental tobacco smoke among adults in Łódz, Poland. Ann Agric Environ Med 2012; 4: 754-761.

42. Parazzini F, La Vecchia C, Negri E, et al. Smoking and risk of endometrial cancer : results from an Italian case - control study. Gynecol Oncol 1995; 23: 55-62.

43. Zhou B, Yang L, Sun $\mathrm{Q}$, et al. Cigarette smoking and the risk of endometrial cancer: a meta-analysis. Am J Med 2008; 121: 501-508.

44. Tzonou A, Lipworth L, Kalandidil A. Dietary factors and the risk of endometrial cancer: a case - control study in Greece. Br J Cancer 1996; 73: $1284-1290$

45. Parazzini F, La Vecchia C, Bocciolone L, Franceschi S. The epidemiology of endometrial cancer. Gynecol Oncol 1991; 41: 1-16.

46. Bergier J. Studies and measurements of physical activity of the society. Ann Agric Environ Med 2012; 3: 329-331.

47. Pan SY, Johnson KC, Ugnat AM. Association of Obesity and Cancer Risk in Canada. Am J Epidemiol 2004; 159: 259-268.
48. Bandera EV, Kushi LH, Moore DF, et al. Consumption of animal foods and endomerial cancer risk: a systematic literature review and metaanalysis. Cancer Causes Control 2007; 18: 967-988.

49. Kushi LH, Byers T, Doyle C. American Cancer Society Guidelines on nutrition and physical activity for cancer prevention: reducing the risk of cancer with healthy food choices and physical activity. CA Cancer J Clin 2006; 56: 254-281.

50. Friedenreich CM, Cook LS, Magliocco AM, et al. Case-control study of lifetime total physical activity and endometrial cancer risk. Cancer Causes Control 2010; 21: 1105-1116.

51. Du M, Kraft P, Eliassen $\mathrm{H}$, et al. Physical activity and risk of endometrial adenocarcinoma in the Nurses' Health Study. Int J Cancer 2014; 134: 2707-2716. 